Check for updates

Cite this: Chem. Sci., 2019, 10, 10881

A All publication charges for this article have been paid for by the Royal Society of Chemistry

Received 26th August 2019

Accepted 16th October 2019

DOI: $10.1039 / c 9 s c 04300 d$

rsc.li/chemical-science

\title{
Endoplasmic reticulum targeting fluorescent probes to image mobile $\mathrm{Zn}^{2+} \dagger$
}

\author{
Le Fang, (ID) a Giuseppe Trigiante, ${ }^{b}$ Rachel Crespo-Otero, (D) a Chris S. Hawes, (D) \\ Michael P. Philpott, ${ }^{\text {C }}$ Christopher R. Jones (D) and Michael Watkinson (ID *c
}

\begin{abstract}
$\mathrm{Zn}^{2+}$ plays an important role in the normal function of the endoplasmic reticulum (ER) and its deficiency can cause ER stress, which is related to a wide range of diseases. In order to provide tools to better understand the role of mobile $\mathrm{Zn}^{2+}$ in ER processes, the first custom designed ER-localised fluorescent $\mathrm{Zn}^{2+}$ probes have been developed through the introduction of a cyclohexyl sulfonylurea as an ER-targeting unit with different $\mathrm{Zn}^{2+}$ receptors. Experiments in vitro and in cellulo show that both probes have a good fluorescence switch on response to $\mathrm{Zn}^{2+}$, high selectivity over other cations, low toxicity, ER-specific targeting ability and are efficacious imaging agents for mobile $\mathrm{Zn}^{2+}$ in four different cell lines. Probe 9 has been used to detect mobile $\mathrm{Zn}^{2+}$ changes under ER stress induced by both tunicamycin or thapsigargin, which indicates that the new probes should allow a better understanding of the mechanisms cells use to respond to dysfunction of zinc homeostasis in the ER and its role in the initiation and progression of diseases to be developed.
\end{abstract}

\section{Introduction}

The endoplasmic reticulum (ER), an organelle in eukaryotic cells, serves a number of important cellular roles, such as protein synthesis and transport, protein folding, carbohydrate metabolism, and lipid and steroid synthesis. ${ }^{1}$ Proteins synthesized in the ER are normally properly folded and transported to the Golgi apparatus, however, when there are changes to ER function, resulting from factors such as ageing, genetic mutations, or the environment, unfolded or misfolded proteins are synthesized and accumulate in the $\mathrm{ER},{ }^{2}$ causing ER stress, which activates the unfolded protein response (UPR). ${ }^{3}$ It has been found that ER stress can result in a wide range of diseases, such as inflammation, ${ }^{4,5}$ diabetes $^{6,7}$ and neurodegenerative disorders, ${ }^{8}$ including Parkinson's and Alzheimer's diseases. ${ }^{\mathbf{9}, 10}$ Additionally, the ER acts as an intracellular store for biological mediators, including zinc, which it requires for normal function. ${ }^{11,12}$ For example, it has been found that zinc can be released from thapsigargin- and inositol 1,4,5-trisphosphate (IP3)-sensitive ER storage in cortical neurons. ${ }^{13}$ In light of this, it is unsurprising that a large number of reports demonstrate that

${ }^{a}$ School of Biological and Chemical Science, Queen Mary University of London, The Joseph Priestley Building, Mile End Road, London, E1 4NS, UK

${ }^{b}$ Centre for Cutaneous Research, Institute of Cell and Molecular Science, Barts and The London School of Medicine and Dentistry, Queen Mary University of London, London E1 2AT, UK

${ }^{c}$ The Lennard-Jones Laboratories, School of Chemical and Physical Science, Keele University, ST5 5BG, UK. E-mail:m.watkinson@keele.ac.uk

$\dagger$ Electronic supplementary information (ESI) available. See DOI: 10.1039/c9sc04300d the depletion of zinc transporters and zinc deficiency can cause ER stress and upregulate the UPR, ${ }^{\mathbf{1 4 - 1 8}}$ however, the role of 'free' or 'mobile' zinc in this process is little understood due to the lack of suitable molecular tools to image this subcellular region that exist.

Small molecule fluorescent probes, which have great advantages of high sensitivity and selectivity, low toxicity, and good photophysical properties, are increasingly important tools for the investigation of biological events ${ }^{19-25}$ and there have been extensive efforts in the development of a range of probes to detect mobile zinc. ${ }^{26-30}$ However, a failure to control the probe's subcellular location or indeed their different behaviour across cell lines ${ }^{31}$ limits their utility somewhat. ${ }^{32,33}$ Though there is a clear need for ER localised probes to monitor mobile $\mathrm{Zn}^{2+}$ flux, to our knowledge there are only two such reports that have appeared in the last decade and in both cases ER localisation was adventitious. ${ }^{34,35}$ Thus, there remains a need for effective and reliable methods to localize small molecule $\mathrm{Zn}^{2+}$ probes to target the ER.

The most effective and reliable strategy employed to date to provide organelle targeting capability in small molecule probes has been to incorporate specific organelle targeting vectors into them. For example, the triphenylphosphonium salt (TPP) has been widely demonstrated to be an effective mitochondrial targeting group, ${ }^{36-38}$ whilst basic ethylenediamine ${ }^{39}$ or morpholine $^{\mathbf{4 0 - 4 2}}$ groups have been successfully applied to target the lysosome. However, this strategy has not yet been widely explored in ER localized probes.

Previously we have reported a modular 'click' synthetic methodology to produce an array of biologically targeted $\mathrm{Zn}^{2+}$ 
probes for both extracellular and intracellular imaging of zinc through the incorporation of a range of targeting units. ${ }^{\mathbf{4 3 , 4 4}} \mathrm{We}$ were therefore hopeful that this approach could be further extended towards the development of ER specific probes, provided that a suitable targeting vector could be identified and incorporated in a modular manner utilising our established chemistry. Herein we present our efforts to this end.

\section{Results and discussion}

\section{Probe design and synthesis}

Recently a number of reports have appeared in which the methyl sulfonamide group has been used as a targeting unit to visualize hydrogen peroxide, ${ }^{45}$ methylglyoxal, ${ }^{46}$ hypochlorite ${ }^{47}$ and hydrogen sulfide ${ }^{48}$ in the ER. Inspired by this, we first synthesized fluorescent probe 1 (ref. 49) using our modular synthetic protocol that incorporated the methyl sulfonamide unit (Fig. 1) and whilst the fluorescence response of the probe to $\mathrm{Zn}^{2+}$ was efficacious in vitro and it co-localised to the ER with ER tracker red, it was unfortunately also widely dispersed in other organelles in HeLa cells.

We therefore decided to employ a revised strategy based on the incorporation of glibenclamide as the targeting unit. Glibenclamide, an antidiabetic drug, is employed in the commercial dyes ER tracker red and ER tracker green because it binds and inhibits ATP-sensitive $\mathrm{K}^{+}$channels that are abundant in the ER membrane. ${ }^{50,51}$ We were further encouraged by a report of the use of glibenclamide as a targeting group in a small molecule chemical probe which was shown to selectively accumulate in the ER and image glutathione. ${ }^{52}$ We therefore
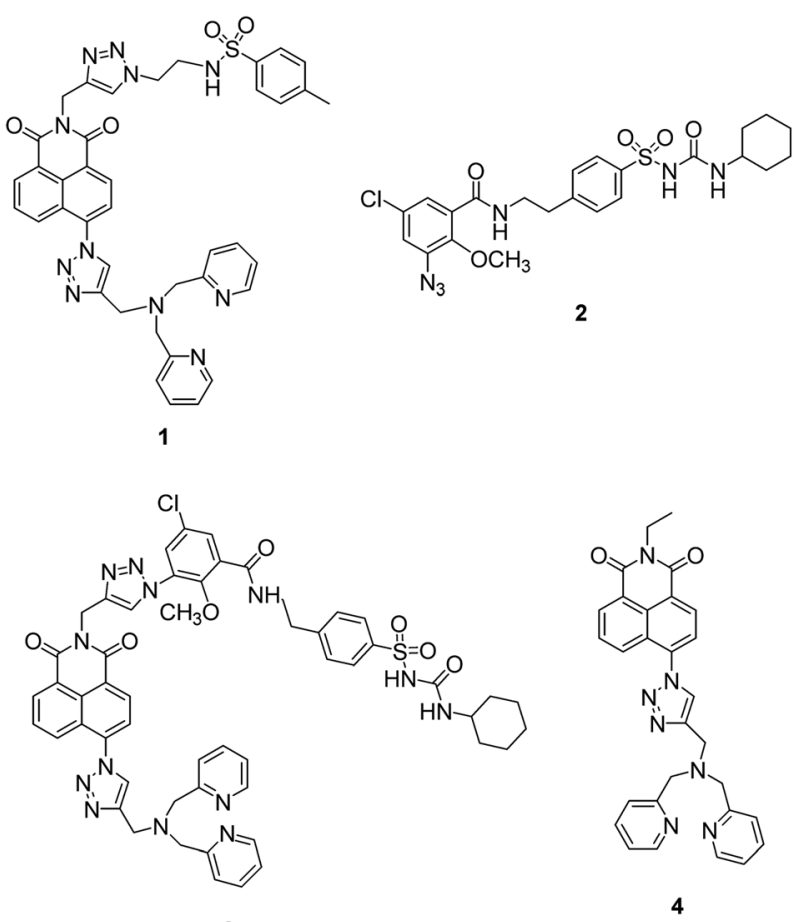

Fig. 1 The structure of probe 1, glibenclamide azide 2, unsuccessfully synthesized probe 3 and non-targeting probe 4 . sought to develop a route to a 'clickable' variant of glibenclamide that we could incorporate into our modular synthetic route and prepared 'click' glibenclamide 2 through six steps in moderate yield (see Scheme S1, ESI $\dagger$ ). Gratifyingly the CuAAC reaction with alkyne $\mathbf{S 6}$ proceeded, as expected, in good yield (Scheme S2, ESI $\dagger$ ), however, to our bemusement, when we came to install the $\mathrm{Zn}^{2+}$ binding unit 8, the second 'click' reaction to give compound 3 failed completely despite a range of $\mathrm{Cu}(\mathrm{I})$ sources being tested. Given the success of the first 'click' reaction we decided to investigate the development of a 'reverse' methodology in which the metal-binding unit was first installed into anhydride S9 before addition of the targeting unit via a second 'click' process was attempted (see ESI, Scheme S3†). Although the first 'click' reaction again worked well, the second 'click' reaction to incorporate the glibenclamide azide completely failed.

At this point we decided to review our synthetic strategy and were attracted by a number of recent reports that reveal the cyclohexyl sulfonylurea moiety of glibenclamide is an important element in binding with ATP-sensitive $\mathrm{K}^{+}$channels, which are present in the ER membrane. ${ }^{53-55}$ We therefore designed an alternative route in which this ER targeting unit was directly incorporated into the naphthalimide, which also makes the synthesis route shorter and easier.

To synthesize the probes, we started from 4-(2-aminoethyl) benzenesulfonamide to give ER-targeting group 6 through the route depicted (see Scheme S4, ESI $\dagger$ ) and directly introduced this into the fluorophore through reaction with commercially available 4-bromo-1,8-naphthalic anhydride 5 (Scheme 1). This was then conveniently converted to azide 7 using standard conditions for such $\mathrm{S}_{\mathrm{N}} \mathrm{Ar}$ reactions, which then underwent smooth and high yielding 'click' reactions with alkynes 8 (ref. 56 ) or $10,{ }^{44}$ to yield probes 9 and 12, the latter after deprotection of 11 with TFA. All products were satisfactorily characterized by ${ }^{1} \mathrm{H},{ }^{13} \mathrm{C}$ NMR and IR spectroscopies as well as high-resolution mass spectrometry.

\section{Photophysical properties in solution}

Fluorescence titrations with $\mathrm{Zn}^{2+}$ were first undertaken to show that both probes have a switch-on response to $\mathrm{Zn}^{2+}$. From Fig. 2a and S2 (ESI $\dagger$ ), it can clearly be seen that with increasing $\mathrm{Zn}^{2+}$ equivalents, the fluorescence intensity of probes $\mathbf{9}$ and $\mathbf{1 2}$ increased gradually with about 16 -fold and 4-fold maximal increase, respectively. Subsequent treatment with TPEN $\left(N, N, N^{\prime}, N^{\prime}\right.$-tetrakis(2-pyridinylmethyl)-1,2-ethanediamine), a strong $\mathrm{Zn}^{2+}$ chelator, resulted in the expected decrease in fluorescence with the fluorescence of $\mathbf{9}$ being completely quenched while that of $\mathbf{1 2}$ was partly quenched (Fig. S3, $\operatorname{ESI} \dagger$ ), which is consistent with previous reports. ${ }^{57}$ The Job's plot (Fig. S4, ESI $\dagger$ ) revealed the expected 1:1 binding stoichiometry with $\mathrm{Zn}^{2+}$. The dissociation constants $K_{\mathrm{d}}$ for probes 9 and 12 were obtained through non-linear curve fitting using reported methods ${ }^{58,59}$ at a number of probe concentrations (Fig. S5 and Table S1, ESI $\dagger$ ). However, because of the very low $K_{\mathrm{d}}$ values for these compounds and to mimic the buffered nature of mobile zinc in cellulo, EGTA (ethylene glycol-bis( $\beta$-aminoethyl ether)- 

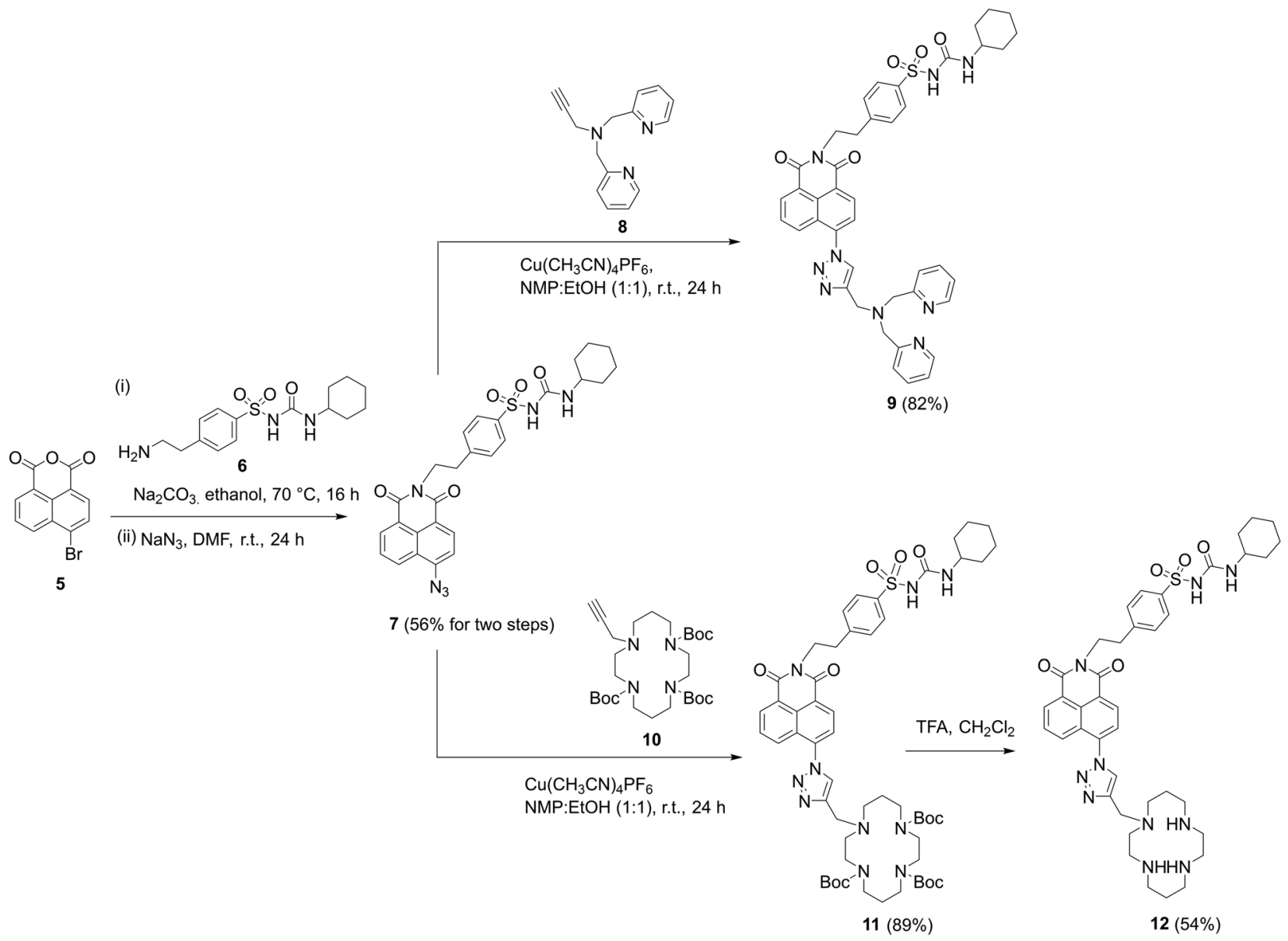

Scheme 1 The successful synthetic route to probes 9 and 12 incorporating cyclohexyl sulfonylurea as the ER targeting unit.

$N, N, N^{\prime}, N^{\prime}$-tetraacetic acid) was used as a competitive chelator $^{27,60,61}$ and the $K_{\mathrm{d}}$ values again calculated at three different concentrations (Fig. S6, ESI $\dagger$ ) with optimal fit being observed at $0.01 \mu \mathrm{M}$ in all cases (Table S2, ESI $\dagger$ ) revealing the dissociation constant of 9 to be $3.5 \mathrm{nM}$ and $4.7 \mathrm{nM}$ for 12. The detection limits of $\mathbf{9}$ and $\mathbf{1 2}$ (Fig. S7, ESI $\dagger$ ) were also estimated to be $47 \mathrm{pM}$ and $0.71 \mathrm{nM}$, respectively.

The quantum yields of both probes were measured using anthracene as the standard ( $\Phi=0.27$ in ethanol). It was found that the quantum yield of 9 was 0.041 , which increased to 0.25 after binding with 1 eq. of $\mathrm{Zn}^{2+}$. In line with our recent report, ${ }^{\mathbf{4 4 , 6 2}}$ the quantum yield of $\mathbf{1 2}$ was much lower, 0.013 and only increased to 0.041 for the complex with 1 equivalent of $\mathrm{Zn}^{2+}$ (Fig. S8, ESI $\dagger$ ).

The $\mathrm{pH}$-dependent fluorescence response of both probes was tested to confirm that they have fluorescence responses to $\mathrm{Zn}^{2+}$ in the biologically relevant $\mathrm{pH}$ range. Fig. $2 \mathrm{~b}$ shows that 9 has good switch on fluorescence response to $\mathrm{Zn}^{2+}$ over a wide $\mathrm{pH}$ a)

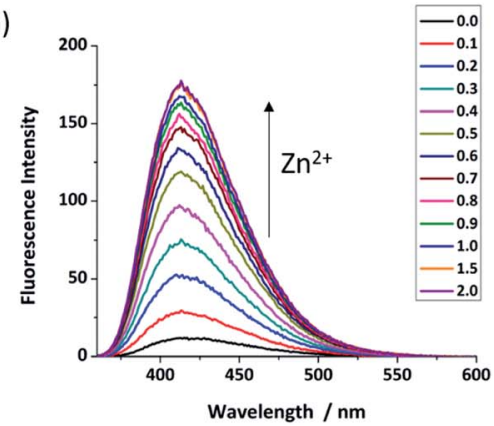

b)

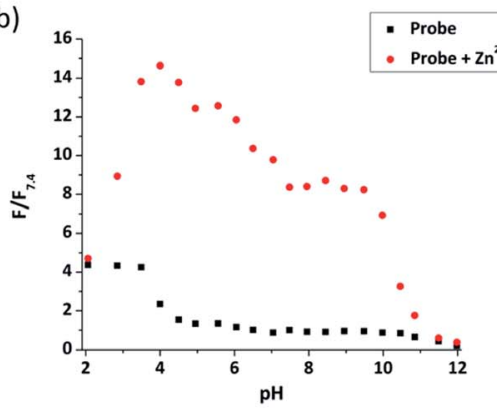

c)

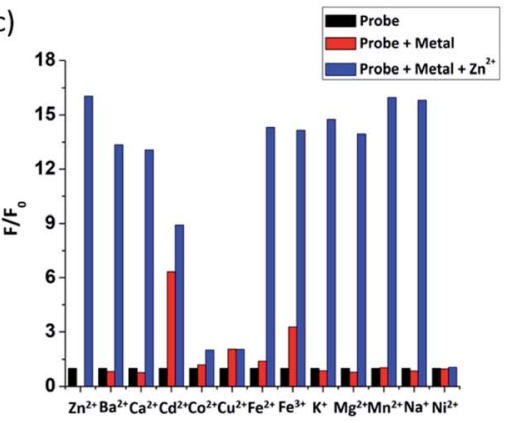

Fig. 2 (a) The fluorescence response of $9(10 \mu \mathrm{M})$ to different equivalents of $\mathrm{ZnCl}_{2}$; (b) the pH profile of 9 (50 $\mu \mathrm{M}$, black dots) and with 1 equivalent $\mathrm{Zn}^{2+}$ (red dots); (c) metal ion selectivity of 9 . Average normalized fluorescence intensities for 9 ( $\left.50 \mu \mathrm{M}\right)$ (black bars), after addition of 5 equivalents of various cations (red bars), followed by addition of 1 equivalent $\mathrm{ZnCl}_{2}$ (blue bars) (for all tests, the solution is $0.01 \mathrm{mM} \mathrm{HEPES} \mathrm{buffer} \mathrm{with} 1 \%$ DMSO, $\mathrm{pH}=7.4$ except $\mathrm{pH}$ profile, $\lambda_{\mathrm{ex}}=346 \mathrm{~nm}, \lambda_{\mathrm{em}}=414 \mathrm{~nm}$, slit width: $5 / 2.5 \mathrm{~nm}$ ). 
range of 3.0-10.0, and the fluorescence of both probe and complex is increased in an acidic environment. In contrast, 12 (Fig. S11, ESI $\dagger$ ) shows a poor response in acid conditions, presumably due to the basic nature of the polyamine ligand, but works well in the $\mathrm{pH}$ range 6.0-12.0; given that the reported $\mathrm{pH}$ of the ER is the same as the cytoplasm, which is about 7.2, ${ }^{63}$ both probes should have a response to mobile $\mathrm{Zn}^{2+}$ in cellulo. Through non-linear curve fitting (applied with the eqn $\mathrm{S}(4)$ and $\mathrm{S}(5)), \uparrow$ the $\mathrm{p} K_{\mathrm{a}}$ values of both probes can be obtained, which are $\mathrm{p} K_{\mathrm{a} 1}=0.81 \pm 0.19, \mathrm{p} K_{\mathrm{a} 2}=4.34 \pm 0.11, \mathrm{p} K_{\mathrm{a} 3}=6.83 \pm 0.53, \mathrm{p} K_{\mathrm{a} 4}$ $=11.63 \pm 0.41$ for 9 , and $\mathrm{p} K_{\mathrm{a} 1}=3.20 \pm 0.14, \mathrm{p} K_{\mathrm{a} 2}=8.07 \pm 0.11$, $\mathrm{p} K_{\mathrm{a} 3}=11.07 \pm 0.58$ for 12 (Fig. S10 and S12, ESI $\dagger$ ). These values are comparable to those reported for related compounds. ${ }^{\mathbf{4 4}}$

The selectivity of the two probes over a range of other competing cations was also investigated. As shown in Fig. 2c, beside $\mathrm{Zn}^{2+}$, the fluorescence of 9 was not switched on obviously after addition of 5 equivalents of other cations, except for the stereoelectronic isostere $\mathrm{Cd}^{2+}$, which is a common issue for many $\mathrm{Zn}^{2+}$ probes, ${ }^{64}$ but is not a problem in biological milieu due to its negligibly low concentration. Subsequent addition of $\mathrm{Zn}^{2+}$ resulted in recovery of a fluorescence response in most cases, however for $\mathrm{Co}^{2+}, \mathrm{Cu}^{2+}$ and $\mathrm{Ni}^{2+}$ fluorescence was not recovered, but as they mostly exist in bound forms in biology, rather than the free cations tested here this is unconcerning. For 12, results were similar, as shown in Fig. S13 (see ESI $\dagger$ ), with only $\mathrm{Cu}^{2+}, \mathrm{Fe}^{2+}$ and $\mathrm{Fe}^{3+}$ continuing to quench fluorescence after the addition of $\mathrm{Zn}^{2+}$. Importantly, the metal ions $\mathrm{Na}^{+}, \mathrm{K}^{+}$, $\mathrm{Ca}^{2+}$ and $\mathrm{Mg}^{2+}$, which are abundant in cells, show no effect on either probe. Overall these results indicate that they should show a selective response to 'mobile' $\mathrm{Zn}^{2+}$ in cellulo.

\section{DFT simulations}

DFT and TDDFT calculations were undertaken to understand the binding behaviour of $\mathbf{9}$ and $\mathbf{1 2}$ with $\mathrm{Zn}^{2+}$ and their excited

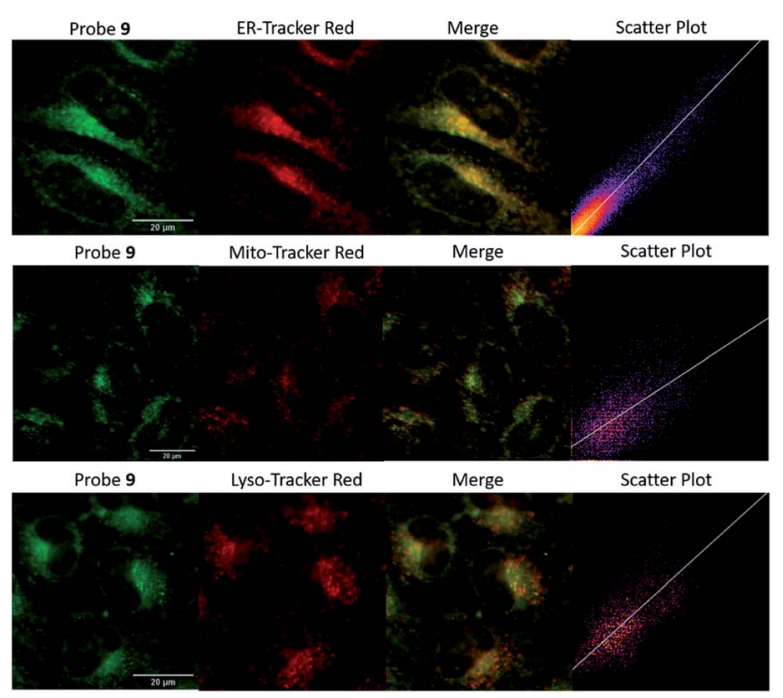

Fig. 3 The colocalization images of HeLa cells incubated with 9 (20 $\mu \mathrm{M}$, GFP filter: $\left.\lambda_{\mathrm{ex}}=470 / 30 \mathrm{~nm}, \lambda_{\mathrm{em}}=530 / 50 \mathrm{~nm}\right)$ and commercial red organelle tracker dyes (RFP filter: $\lambda_{\text {ex }}=530 / 40 \mathrm{~nm}, \lambda_{\mathrm{em}}=605 / 55$ $\mathrm{nm}$ ). (Scale bars $=20 \mu \mathrm{m}$ ). states. The optimised structure of probe 9 with 1 equivalent of $\mathrm{Zn}^{2+}$ (Fig. S14, ESI $\dagger$ ) shows the $\mathrm{Zn}^{2+}$ is bound to the nitrogen in ligand $N, N$-di-(2-picolyl)ethylenediamine (DPEN) and a nitrogen atom of the triazole. For 12 (Fig. S15, ESI $\dagger$ ), the triazole nitrogen is involved in binding with $\mathrm{Zn}^{2+}$ in addition to the cyclam nitrogen donors, which is consistent with previous observations in closely related analogues. ${ }^{\mathbf{6 5 6}}$

The calculated vertical excitations and emissions are in relatively good agreement with experimental data (see Table S3 and S4, ESI $\dagger$ ). The excited state calculations also show that positions of the absorption maximum and the emission energies are not significantly affected by the formation of the complexes with $\mathrm{Zn}^{2+}$ as observed experimentally. This behaviour can be understood by visualising the $S_{1}-S_{0}$ electron density plots (Fig. S16 for 9, Fig. S17 for 12, ESI $\dagger$ ). The electronic transition is localised on the naphthalimide moiety and the vicinal triazole, and that there is no major difference between probes and their complexes with $\mathrm{Zn}^{2+}$; only a slight decrease of electron density on the nitrogen from the triazole is observed when it is involved in complex formation and the oscillator strength is not significantly affected. These calculations indicate that the enhancement of emissive behaviour of the complexes should be related to a reduced decay through nonradiative pathways after

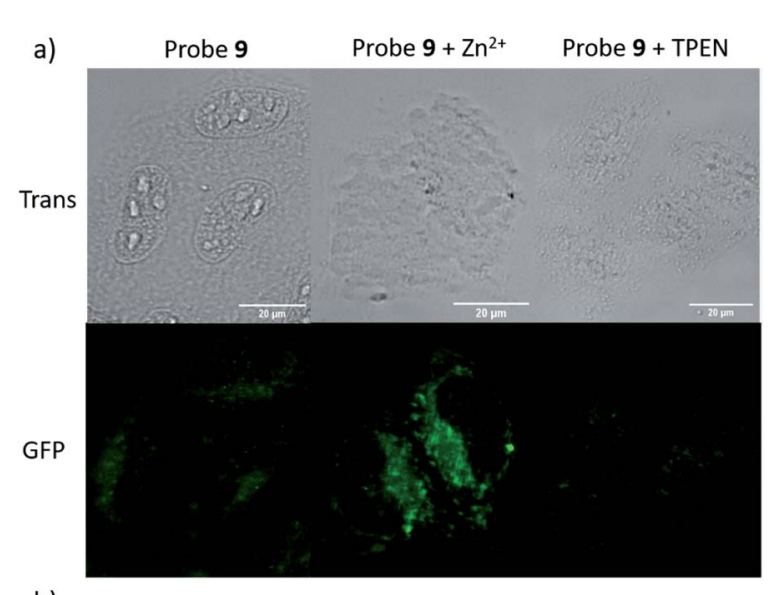

b)

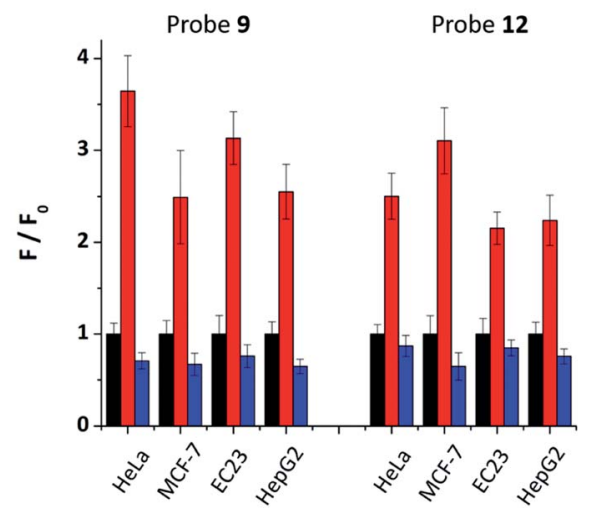

Fig. 4 (a) Fluorescence microscopy images of HeLa cells treated with $9(20 \mu \mathrm{M}), 9(20 \mu \mathrm{M})$ with zinc pyrithione $(100 \mu \mathrm{M})$, and $9(20 \mu \mathrm{M})$ with TPEN $(100 \mu \mathrm{M})($ Scale bars $=20 \mu \mathrm{m})$; $(\mathrm{b})$ the fluorescence intensity $(F)$ in different cell lines in the presence of zinc pyrithione (red bars) or TPEN (blue bars) relative to the intensity of the probe alone $\left(F_{0}\right.$, black bars, normalised to 1 ). 
a)
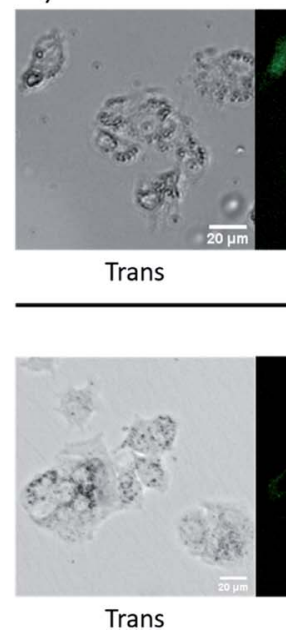

Tunicamycin-induced ER stress

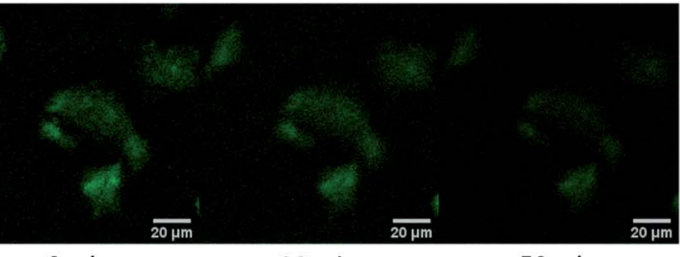

\begin{abstract}
$0 \mathrm{~min}$
\end{abstract}
Thapsigargin-induced ER stress

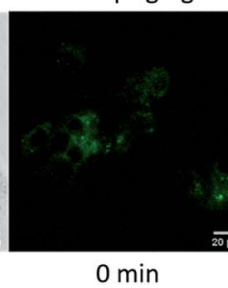

$20 \mathrm{~min}$

$50 \mathrm{~min}$

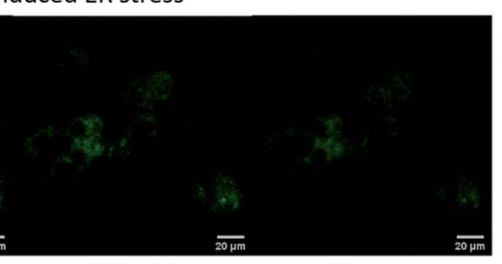

b)

Fig. 5 (a) Fluorescence microscopy images and (b) fluorescence intensity changes of probe 9 (20 $\mu$ M) in HepG2 cells at ER stress state induced by tunicamycin $\left(5 \mu \mathrm{g} \mathrm{mL}^{-1}\right)$ or thapsigargin $(1 \mu \mathrm{M})$. (Scale bars $\left.=20 \mu \mathrm{m}\right)$.

complexation with $\mathrm{Zn}^{2+}$ in contrast with the typical PET mechanism. The role of alternative mechanisms to PET in enhancing the fluorescence of organometallic complexes has been recently highlighted..$^{67,68}$ The formation of the complex hinders large amplitude vibrations in the vicinity of the fluorophore hampering access to nonradiative mechanisms and increasing the quantum yield of emission. The restriction of intramolecular rotations can also hinder the access to low energy conical intersections associated with ultrafast decay to the ground state. Tang et al. have recently shown how restriction of intramolecular motions in a $\mathrm{Zn}^{2+}$ complex can hamper the access to a dark state enhancing the fluorescence response. ${ }^{69}$

\section{ER-targeting ability}

Encouraged by the promising properties of 9 and 12 in vitro, we attempted to assess their suitability for imaging $\mathrm{Zn}^{2+}$ in cells. Firstly, the innate toxicity of them was measured by alamarBlue assays with HeLa cells (Fig. S18 and S19, ESI †). ${ }^{22}$ The cell viabilities were over $90 \%$ after $24 \mathrm{~h}$ incubation with both probes in a concentration range 10-50 $\mu \mathrm{M}$ compared to the control group, demonstrating both have very low cytotoxicity. ${ }^{70}$

The targeting behaviour of $\mathbf{9}$ and $\mathbf{1 2}$ was then studied using co-staining assays. HeLa cells were co-incubated with $\mathbf{9}$ and ERtracker red, and as shown in Fig. 3, the fluorescence of $\mathbf{9}$ from the green channel overlays well with that of ER-tracker red, which was obtained from the red channel, giving an excellent Pearson's correlation coefficient of 0.92 . The negative controls of 9 co-incubated with Mito-tracker red and Lyso-tracker red, did not reveal a good overlay and Pearson's correlation coefficients were 0.52 and 0.58 , respectively. Similar results were observed for 12 (see Fig. S22, ESI $\dagger$ ) with Pearson's coefficients of $0.85,0.52,0.45$ being measured for the ER, mitochondria and lysosome respectively. A control probe that did not contain a targeting unit 4 (ref. 49) was observed to be widely distributed in all three organelles (Fig. S23, ESI $\dagger$ ) and this is also consistent with our original study ${ }^{65}$
To confirm the probes have ER-targeting ability in different cell types, a human breast cancer cell line MCF-7, a sweat gland tissue cell line EC23 and a human liver cancer cell line HepG2 were used to study the ER-targeting behaviour. The results (see Fig. S24-S26 for probe 9, Fig. S27-S29 for probe 12, ESI $\dagger$ ) show that probe localisation is similar to that observed in HeLa cells demonstrating the general applicability of the probes. Based on these data, we can conclude that both $\mathbf{9}$ and $\mathbf{1 2}$ show excellent, and general, ER-targeting capability.

\section{$\mathrm{Zn}^{2+}$ fluorescence response in cells}

As 9 and 12 can localise to the ER, their fluorescence response to 'mobile' $\mathrm{Zn}^{2+}$ in cellulo was tested to demonstrate that they have the ability to image $\mathrm{Zn}^{2+}$ in the ER. As shown in Fig. 4a, the fluorescence response of probe $\mathbf{9}$ in HeLa cells could be clearly observed in the ER. Upon the addition of zinc pyrithione, a membrane permeable zinc source, the fluorescence intensity increased considerably; the addition of TPEN resulted in almost complete quenching of fluorescence, as expected from in vitro control experiments. The fluorescence intensity read from these images (Fig. 4b) clearly reveals these changes. For example, in HeLa cells the intensity of the fluorescence response increases 3.6 times after the addition of zinc pyrithione and decreases by $30 \%$ on addition of TPEN compared to that observed for 9 alone. Similar results were observed in other cell lines and also for 12 (Fig. 4b and S30-S36, ESI†) demonstrating that both probes are tractable in their ability to image mobile $\mathrm{Zn}^{2+}$ in cellulo.

\section{Fluorescence change under ER stress}

As 9 shows excellent ER-localisation and $\mathrm{Zn}^{2+}$ response, we sought to explore whether it could be applied to monitor changes in mobile $\mathrm{Zn}^{2+}$ levels. It is reported that ER stress can be induced by tunicamycin and thapsigargin with tunicamycin causing unfolded protein accumulation and thapsigargin 
reducing $\mathrm{Ca}^{2+}$ levels. As shown in Fig. 5, the fluorescence intensity of 9 in HepG2 cells decreased significantly after treatment with both ER stress inducers, indicating that the mobile $\mathrm{Zn}^{2+}$ level in the ER was significantly depleted under ER stress within 1 hour. As a control, no fluorescence intensity change was observed in their absence (Fig. S37, ESI† $\dagger$ ).

\section{Conclusions}

In conclusion, the ER localised fluorescent probes $\mathbf{9}$ and $\mathbf{1 2}$ have been developed to image mobile $\mathrm{Zn}^{2+}$ in the ER through the introduction of a simple sulfonylurea targeting group. They show a good fluorescence response to $\mathrm{Zn}^{2+}$, high selectivity over biologically relevant competing cations, and can be used to detect $\mathrm{Zn}^{2+}$ over a wide range of $\mathrm{pH}$ in vitro. Their low toxicity, ER-targeting and ability to image mobile $\mathrm{Zn}^{2+}$ in different cell lines should allow them to be applied in imaging $\mathrm{Zn}^{2+}$ related biological processes in the ER. The fluorescence intensity of 9 was also shown to decrease under ER stress inducers, indicating that mobile $\mathrm{Zn}^{2+}$ levels are reduced. The ER localised probes may therefore provide a platform to understand the mechanisms cells use to respond to dysfunction of zinc homeostasis in the ER, and to develop a better understanding of the role of $\mathrm{Zn}^{2+}$ in the initiation and progression of related diseases.

\section{Conflicts of interest}

There are no conflicts to declare.

\section{Acknowledgements}

We acknowledge the EPSRC National Mass Spectrometry Service, University of Wales, Swansea for the provision of highresolution mass spectrometry. DFT calculations were performed on Queen Mary's Apocrita HPC facility, supported by QMUL Research-IT. LF is grateful to the Chinese Scholarship Council for the provision of a PhD studentship.

\section{References}

1 D. S. Schwarz and M. D. Blower, Cell. Mol. Life Sci., 2016, 73, 79-94.

2 H. Yoshida, FEBS J., 2007, 274, 630-658.

3 K. Mori, Cell, 2000, 101, 451-454.

4 K. Zhang and R. J. Kaufman, Nature, 2008, 454, 455-462.

5 A. D. Garg, A. Kaczmarek, O. Krysko, P. Vandenabeele, D. V. Krysko and P. Agostinis, Trends Mol. Med., 2012, 18, 589-598.

6 D. L. Eizirik, A. K. Cardozo and M. Cnop, Endocr. Rev., 2008, 29, 42-61.

7 S. H. Back and R. J. Kaufman, Annu. Rev. Biochem., 2012, 81, 767-793.

8 C. Hetz and S. Saxena, Nat. Rev. Neurol., 2017, 13, 477-491.

9 J. H. Lin, P. Walter and T. Benedict Yen, Annu. Rev. Phytopathol., 2008, 3, 399-425.

10 L. Ozcan and I. Tabas, Annu. Rev. Med., 2012, 63, 317-328.
11 Y. Hattori, H. Koseki, T. Sato, H. Ohno, T. Watanabe, H. Izumi, T. Hara, W. Ohashi, T. Fukada, K. Hase, A. Hijikata, T. Iwanaga, K. Mishima, Y. Furusawa, O. Ohara, T. Irié, H. Mori, S. Robine, H. Watarai and S. Kimura, PLoS Genet., 2016, 12, e1006349.

12 C. D. Ellis, F. Wang, C. W. MacDiarmid, S. Clark, T. Lyons and D. J. Eide, J. Cell Biol., 2004, 166, 325-335.

13 C. J. Stork and Y. V. Li, J. Mol. Signaling, 2010, 5, 1-6.

14 M.-H. Kim, T. B. Aydemir, J. Kim and R. J. Cousins, Proc. Natl. Acad. Sci. U. S. A., 2017, 114, E5805-E5814.

15 M. Wang, Q. Xu and M. Yuan, Plant Signaling Behav., 2011, 6, 77-79.

16 C. Giunta, J. M. Walker, A. E. Palmer, J. Jeong, B. Steinmann, M. Rohrbach, D. J. Eide, J. G. Park and F. Wang, Proc. Natl. Acad. Sci. U. S. A., 2012, 109, E3530-E3538.

17 T. S. Le Nguyen, K. Kohno and Y. Kimata, Biosci., Biotechnol., Biochem., 2013, 77, 1337-1339.

18 Z. Zhou, D. Dong, W. Zhang, Q. Li, Q. Sun, X. Sun, X. Sun, W. Zhong and X. Tan, Am. J. Physiol. Gastrointest. Liver Physiol., 2015, 308, G757-G766.

19 D. Wu, A. C. Sedgwick, T. Gunnlaugsson, E. U. Akkaya, J. Yoon and T. D. James, Chem. Soc. Rev., 2017, 46, 71057123.

20 Y. Chen, Y. Bai, Z. Han, W. He and Z. Guo, Chem. Soc. Rev., 2015, 44, 4517-4546.

21 H. M. Kim and B. R. Cho, Chem. Rev., 2015, 115, 5014-5055. 22 D. Ding, K. Li, B. Liu and B. Z. Tang, Acc. Chem. Res., 2013, 46, 2441-2453.

23 H. M. Kim and B. R. Cho, Acc. Chem. Res., 2009, 42, 863-872.

24 L. Yuan, W. Lin, K. Zheng and S. Zhu, Acc. Chem. Res., 2013, 46, 1462-1473.

25 M. H. Lee, J. S. Kim and J. L. Sessler, Chem. Soc. Rev., 2015, 44, 4185-4191.

26 G. K. Walkup, S. C. Burdette, S. J. Lippard and R. Y. Tsien, J. Am. Chem. Soc., 2000, 122, 5644-5645.

27 T. Hirano, K. Kikuchi, Y. Urano, T. Higuchi and T. Nagano, J. Am. Chem. Soc., 2000, 122, 12399-12400.

28 F. Qian, C. Zhang, Y. Zhang, W. He, X. Gao, P. Hu and Z. Guo, J. Am. Chem. Soc., 2009, 131, 1460-1468.

29 S. Chen, R. Bleher, S. A. Garwin, T. V. O'Halloran, T. K. Woodruff, A. R. Bayer, B. Y. Kong, E. L. Que, F. E. Duncan, S. C. Gleber, V. P. Dravid and S. Vogt, Nat. Chem., 2014, 7, 130-139.

30 J. M. Goldberg, F. Wang, C. D. Sessler, N. W. Vogler, D. Y. Zhang, W. H. Loucks, T. Tzounopoulos and S. J. Lippard, J. Am. Chem. Soc., 2018, 140, 2020-2023.

31 W. Maret, Metallomics, 2015, 7, 202-211.

32 H. Zhu, J. Fan, J. Du and X. Peng, Acc. Chem. Res., 2016, 49, 2115-2126.

33 W. Xu, Z. Zeng, J. H. Jiang, Y. T. Chang and L. Yuan, Angew. Chem., Int. Ed., 2016, 55, 13658-13699.

34 W. Lin, D. Buccella and S. J. Lippard, J. Am. Chem. Soc., 2013, 135, 13512-13520.

35 X. Gan, P. Sun, H. Li, X. Tian, B. Zhang, J. Wu, Y. Tian and H. Zhou, Biosens. Bioelectron., 2016, 86, 393-397.

36 H. M. Kim, C. S. Lim, G. Masanta, H. J. Kim, B. R. Cho and J. H. Han, J. Am. Chem. Soc., 2011, 133, 5698-5700. 
37 H. M. Kim, B. R. Cho, G. Masanta, C. S. Lim, C. H. Heo and N. Y. Baek, Chem. Commun., 2012, 48, 4546.

38 Z. Guo, Z. Liu, W. He, C. Zhang and Y. Chen, Chem. Commun., 2012, 48, 8365.

39 Q. Liu, D. Zhu, H. Jiang, L. Xue and G. Li, Inorg. Chem., 2012, 51, 10842-10849.

40 H. Zhu, J. Fan, S. Zhang, J. Cao, K. Song, D. Ge, H. Dong, J. Wang and X. Peng, Biomater. Sci., 2014, 2, 89-97.

41 H. J. Lee, C. W. Cho, H. Seo, S. Singha, Y. W. Jun, K. H. Lee, Y. Jung, K. T. Kim, S. Park, S. C. Bae and K. H. Ahn, Chem. Commun., 2016, 52, 124-127.

42 C. Du, S. Fu, X. Wang, A. C. Sedgwick, W. Zhen, M. Li, X. Li, J. Zhou, Z. Wang, H. Wang and J. L. Sessler, Chem. Sci., 2019, 10, 5699-5704.

43 J. Pancholi, D. J. Hodson, K. Jobe, G. A. Rutter, S. M. Goldup and M. Watkinson, Chem. Sci., 2014, 5, 3528-3535.

44 L. Fang, G. Trigiante, C. J. Kousseff, R. Crespo-Otero, M. P. Philpott and M. Watkinson, Chem. Commun., 2018, 54, 9619-9622.

45 H. Xiao, P. Li, X. Hu, X. Shi, W. Zhang and B. Tang, Chem. Sci., 2016, 7, 6153-6159.

46 M. Yang, J. Fan, J. Zhang, J. Du and X. Peng, Chem. Sci., 2018, 9, 6758-6764.

47 J.-T. Hou, H. S. Kim, C. Duan, M. S. Ji, S. Wang, L. Zeng, W. Ren and J. S. Kim, Chem. Commun., 2019, 2533-2536.

48 W. Lin, G. Xu, S. Gao, Y. Ma, Y. Tang and A. Xu, Sci. Rep., 2017, 7, 1-9.

49 L. Fang, G. Trigiante, R. Crespo-Otero, M. P. Philpott, C. R. Jones and M. Watkinson, Org. Biomol. Chem., DOI: 10.1039/c9ob01855g, in press.

50 S. Phaniraj, Z. Gao, D. Rane and B. R. Peterson, Dyes Pigm., 2016, 135, 127-133.

51 D. Greentree, É. Rousseau, J. Teijeira, K. Côté and L. Picard, J. Mol. Cell. Cardiol., 2004, 34, 1163-1172.

52 S. J. Kim, Y. Wi, J. S. Kim, J. E. Song, K. Sunwoo, H. Y. Yoon, G. Han, H. T. Le, P. Verwilst, C. Kang and T. W. Kim, Chem. Commun., 2018, 54, 8897-8900.

53 J. L. Challinor-Rogers, D. C. Kong, M. N. Iskander and G. A. McPherson, J. Pharmacol. Exp. Ther., 1995, 273, 778786.
54 E. Yuriev, D. C. M. Kong and M. N. Iskander, Eur. J. Med. Chem., 2004, 39, 835-847.

55 N. R. Johnston, R. K. Mitchell, E. Haythorne, M. P. Pessoa, F. Semplici, J. Ferrer, L. Piemonti, P. Marchetti, M. Bugliani, D. Bosco, E. Berishvili, P. Duncanson, M. Watkinson, J. Broichhagen, D. Trauner, G. A. Rutter and D. J. Hodson, Cell Metab., 2016, 24, 389-401.

56 J. Chaignon, S. E. Stiriba, F. Lloret, C. Yuste, G. Pilet, L. Bonneviot, B. Albela and I. Castro, Dalton Trans., 2014, 43, 9704-9713.

57 L. E. Mcquade and S. J. Lippard, Inorg. Chem., 2010, 49, 9535-9545.

58 P. Thordarson, Chem. Soc. Rev., 2011, 6, 1305-1323.

59 D. B. Hibbert and P. Thordarson, Chem. Commun., 2016, 52, 12792-12805.

60 C. J. Fahrni and T. V. O. Halloran, J. Am. Chem. Soc., 1999, 121, 11448-11458.

61 M. Taki, J. L. Wolford and T. V. O. Halloran, J. Am. Chem. Soc., 2004, 126, 712-713.

62 K. Jobe, C. H. Brennan, M. Motevalli, S. M. Goldup and M. Watkinson, Chem. Commun., 2011, 47, 6036-6038.

63 M. M. Wu, J. Llopis, S. Adams, J. M. McCaffery, M. S. Kulomaa, T. E. Machen, H. P. H. Moore and R. Y. Tsien, Chem. Biol., 2000, 7, 197-209.

64 J. Wang, Y. Xiao, Z. Zhang, X. Qian, Y. Yang and Q. Xu, J. Mater. Chem., 2005, 15, 2836-2839.

65 E. Tamanini, A. Katewa, L. M. Sedger, M. H. Todd and M. Watkinson, Inorg. Chem., 2009, 48, 319-324.

66 E. Tamanini, K. Flavin, M. Motevalli, S. Piperno, L. A. Gheber, M. H. Todd and M. Watkinson, Inorg. Chem., 2010, 49, 3789-3800.

67 H. Su, X. Chen and W. Fang, Anal. Chem., 2014, 86, 891-899.

68 D. Escudero, Acc. Chem. Res., 2016, 49, 1816-1824.

69 Y. Tu, J. Liu, H. Zhang, Q. Peng, J. W. Y. Lam and B. Z. Tang, Angew. Chem., 2019, 131, 15053-15056.

70 A third probe S16 (see ESI $\dagger$ ) proved to be cytotoxic and was not taken forward to studies in cellulo. 